\title{
Pharmacognostical Standardization, Phytochemical Investigation, and Anthelminthic Activity of Arisaema propinquum Schott Rhizomes
}

\author{
Prince Ahad Mir, Roohi Mohi-ud-din', Mohd. Akbar Dar', Ghulam Nabi Bader ${ }^{1}$ \\ Amritsar Pharmacy College, Punjab Technical University, Amritsar, Punjab, 'Department of Pharmaceutical Sciences, University of Kashmir, Srinagar, \\ Jammu and Kashmir, India
}

\begin{abstract}
Ethnopharmacology: Arisaema propinquum Schott (Araceae) is commonly known as cobra lily. Traditionally, the rhizomes were used as vermifuge, in rheumatism, as stomachache, and in snake bites. Objectives:The present study was designed to evaluate the pharmacognostical parameters and anthelminthic activity of $A$. propinquum rhizomes. Materials and Methods: The rhizomes of $A$. propinquum Schott was collected, shade dried and then powdered, and then evaluated for pharmacognostic parameters such as macro- and microscopical characters, physico-chemical parameters, and phytochemical analysis using standard procedures. Anthelminthic activity of the extracts was elevated against Pheretima posthuma. Results: The rhizomes are light brown in color with pungent odor and astringent taste. Transverse section of rhizomes showed intercellular schizogenous cavities, xylem vessels, phloem vessels, and parenchymatous cells. Phytochemical screening of the extracts reveals the presence of alkaloids, carbohydrates, cardiac glycosides, coumarins, proteins, amino acids, phenols, tannins, flavonoids, saponins, steroids, and terpenoids. Physiochemical parameters including ash values showed $6.32 \%$ total ash, $1.77 \%$ acid insoluble ash, $5.15 \%$ water-soluble ash, and $8.55 \%$ sulfated ash. Other parameters such as extractive value, foreign matter, moisture content, swelling index, foaming index, $\mathrm{pH}$ of different solvents, and fluorescence analysis were also determined. Both the methanolic and aqueous extracts of $A$. propinquum showed dose-dependent anthelminthic activity against $P$. posthuma compared to standard albendazole. Conclusion: This is the first report on the pharmacognostic studies and anthelminthic activity of $A$. propinquum Schott. Data composed from such studies can be used as a standard in the quality control of this plant used as an herbal medicine for the treatment of various diseases.

Key words: Anthelminthic, Arisaema propinquum, pharmacognostical standardization, Pheretima posthuma, phytochemical investigation

\section{SUMMARY}

- In the present era, the use of herbal products and herbal formulations are predominantly increased due to their least side effect and tremendous level of active ingredients. Till date, no detailed standardized work has been reported for this plant. The pharmacognostical parameters such as acid values, extractive values, foaming index, swelling index, fluorescence analysis, and preliminary phytochemical screening provide significant information by which one can easily authenticate the crude drug and also check the adulteration for the quality of raw material. The pharmacognostic parameters studied during the present research work are being reported for the first time and will be quite beneficial for the identification of herbal plant and also for the preparation of herbal monographs. The present study will also be helpful in differentiating the present species from its closely related species of the same genus and family.

- Indian adult earthworms (Pheretima posthuma) were used for studying
\end{abstract}

Anthelminthic activity of the herbal drugs in the present study as they share similar anatomical and physiological resemblance with the helminthic parasites of humans. In the present work, both methanolic and aqueous extracts of $A$. propinquum Schott showed good anthelmintic activity in a dosage-dependent manner as compared to aqueous and standard drug albendazole.

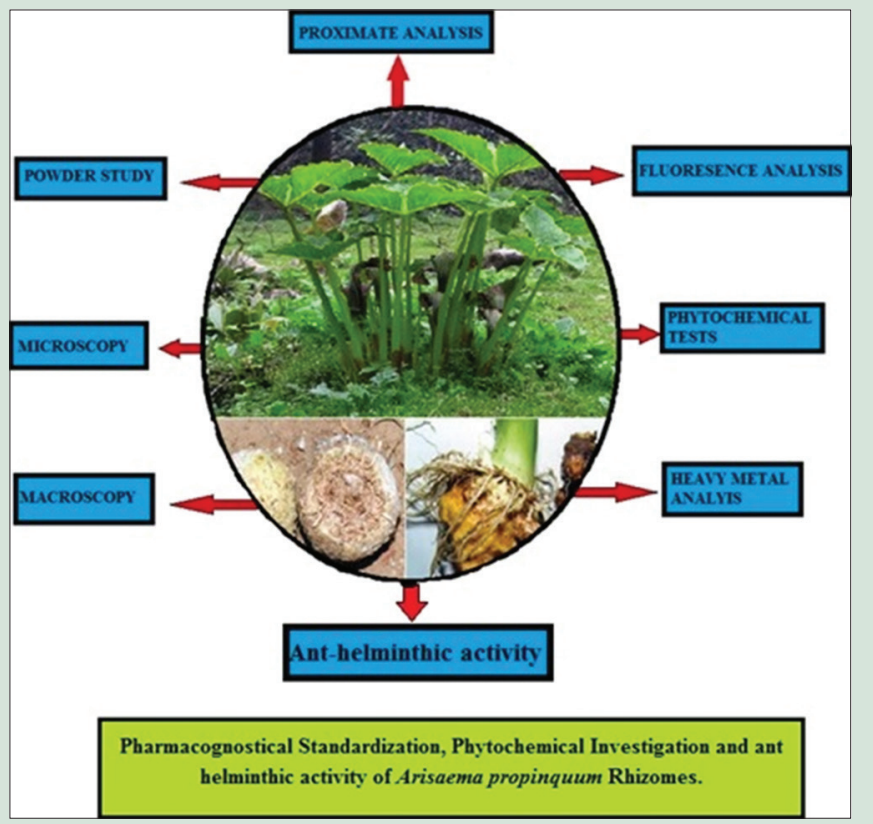

Abbreviations Used: TS: Transverse section; SE Tibet: Southeast Tibet; HIV: Human immunodeficiency virus; CBT: Centre for Biodiversity and Taxonomy; SEM: Standard error of mean.

\section{Correspondence:}

Dr. Prince Ahad Mir,

Amritsar Pharmacy College, 12 KM Stone,

Amritsar Jalandhar, GT Road, Amritsar - 143 001, Punjab, India.

E-mail: Princeahad@kashmiruniversity.net DOI: 10.4103/pr.pr_106_19

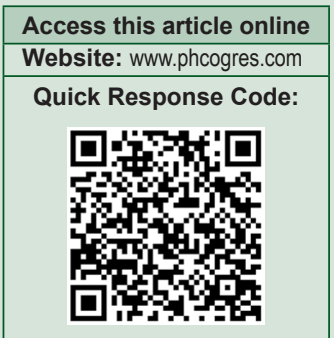

\section{INTRODUCTION}

The genus Arisaema, commonly known as cobra lilies, comprised more than 399 herbaceous species belonging to family Araceae. Arisaema propinquum Schott is commonly known as Wallich's cobra lily or cobra lily, and in Kashmir, the plant is known as Hapat-makei or Hapat-mundh. A. propinquum Schott is a tuberous plant that grows at an altitude of $2400-3600 \mathrm{~m}$. The plant is widely distributed throughout temperate to tropical areas, mainly distributed in the Himalayas, from Kashmir to
This is an open access journal, and articles are distributed under the terms of the Creative Commons Attribution-NonCommercial-ShareAlike 4.0 License, which allows others to remix, tweak, and build upon the work non-commercially, as long as appropriate credit is given and the new creations are licensed under the identical terms.

For reprints contact: reprints@medknow.com

Cite this article as: Mir PA, Mohi-ud-din R, Dar MA, Bader GN. Pharmacognostical standardization, phytochemical investigation, and anthelminthic activity of Arisaema propinquum Schott rhizomes. Phcog Res 2020;12:181-5. 
Southeast Tibet. ${ }^{[1]}$ The plant grows up to 5-6 feet in height with three large yellowish-green glossy leaves. The spathe or hood is thick at the base and ends in a pointy beak, which comprised 8-20 $\mathrm{cm}$ wipe such as long tongue emerging out from inside. At the curvature of the hood, there is a white netting effect which presents the side edges such as a stained window. Leaf stalk and stem are often brown-spotted. The plant flowers in the month of May-June. ${ }^{[2]}$ Traditionally, the dried leaves, fruits, and roots are used to treat diabetic neuropathy, rheumatoid arthritis, ${ }^{[3]}$ chronic boils, and skin eruptions. ${ }^{[4]}$ Pastes prepared from the roots were applied externally for the treatment of erysipelas and scabies. ${ }^{[5]}$

Helminthiasis or worm infection is among the most prevalent infections, effecting billions of people throughout the world. ${ }^{[6]}$ The disease spreads by contamination or inadequate sanitation. ${ }^{[7]}$ The helminthic disease decreases the immune responses to various pathogens and leads to serious clinical complications such as undernourishment, anemia, eosinophilia, pneumonia, ${ }^{[8]}$ malaria, tuberculosis, and human immunodeficiency virus. ${ }^{[9]}$ Due to the resistance of gastrointestinal helminthes to various available anthelminthic drugs, the demand for natural anthelmintics is increasing extremely day by day. ${ }^{[10,11]}$ Indian adult earthworms (Pheretima posthuma) were used for studying anthelminthic activity of the herbal drugs in the present study as they share similar anatomical and physiological resemblance with the helminthic parasites of humans.

\section{MATERIALS AND METHODS}

\section{Collection of plant material and authentication}

The rhizomes of A. propinquum Schott were collected from Doodhpathri area of Budgam district at $2730 \mathrm{~m}$ in the month of July 2013. The plant was identified and authenticated by Dr. Akhtar H. Malik, Taxonomist, Centre for Biodiversity and Taxonomy, Department of Botany, University of Kashmir, with reference number 1896-KASH.

\section{Chemicals and reagents}

All the chemicals used were of analytical grade and were procured from registered dealers such as HiMedia Laboratories Pvt. Ltd., Mumbai, and Central Drug House Ltd., New Delhi, India.

\section{Macroscopical and Microscopical Evaluation}

Macroscopical and microscopical evaluations of A. propinquum Schott were studied according to the methods described in Trease and Evans Pharmacognosy..$^{[12,13]}$ The study was carried out to prevent adulteration which mainly occurs during the selection procedures of raw medicinal material from genus Arisaema.

\section{Preparation of extracts}

The fresh air-dried rhizomes of A. propinquum Schott was powdered and then subjected to hot extraction using methanol as a solvent in a Soxhlet apparatus. Aqueous extract was prepared by the decoction method. The extracts obtained were filtered through Whatman filter paper and concentrated under reduced pressure using a rotary vacuum evaporator. The extracts were then dried and transferred in a closed airtight container for further use.

\section{Physiochemical analysis}

The physicochemical analysis of $A$. propinquum Schott rhizomes was carried out by determining ash values, extractive values, foreign organic matter, moisture content, and $\mathrm{pH}$ of different solvents. ${ }^{[14]}$ Other parameters such as swelling index, foaming index, ${ }^{[15]}$ total tannin content, and total fat content ${ }^{[16]}$ were also determined.

\section{Fluorescence analysis}

Many herbs show fluorescence when cut surface or powder is exposed to ultraviolet (UV) light, and this can be useful in their identification. The fluorescence character of the powdered plant parts (40 mesh) was studied both in daylight and UV light (254 and $366 \mathrm{~nm}$ ) and after treatment with different reagents such as sodium hydroxide, picric acid, acetic acid, hydrochloric acid, nitric acid, iodine, and ferric chloride. ${ }^{[17,18]}$

\section{Phytochemical investigation}

Weighed quantity of plant material was extracted separately with petroleum ether, chloroform, ethyl acetate, methanol, and water by hot extraction method. The extracts obtained were subjected to preliminary phytochemical investigation for the detection of following compounds: carbohydrates, protein, amino acids, fats and oils, sterols and steroids, glycoside, coumarins, flavonoids, alkaloids, tannins and phenolic compounds, acidic compounds, saponins, terpenes and terpenoids, mucilage resins, and lipids/fats. ${ }^{[19,20]}$

\section{Heavy metal analysis \\ Wet digestion procedure}

$1.0 \mathrm{~g}$ of plant material was digested with $5 \mathrm{~mL}$ mixture of nitric and perchloric acids in a digestion flask. The mixture was heated at $110^{\circ} \mathrm{C}$ until the solution became clear, indicating the complete digestion of the organic matter. The mixture was allowed to cool at room temperature. The digested solution was then diluted with $100 \mathrm{~mL}$ of deionized water and was analyzed using an atomic absorption spectrometer (AAS) for the determination of lead, copper, cadmium, and chromium. ${ }^{[21]}$

\section{Anthelminthic activity study}

Earthworms were collected locally from Hazratbal district, Srinagar. Earthworms of $6-8 \mathrm{~cm}$ in length and $0.2-0.4 \mathrm{~cm}$ in width were collected and washed thoroughly in saline water to remove the external debris to be used for anti-helminthic activity. The earthworms were acclimatized to the laboratory condition before experimentation. The earthworms were divided into 6 groups of 5 earthworms in each and placed in Petri dishes containing $15 \mathrm{~mL}$ of sample/drug solutions, as mentioned below: Group 1: Received 2\% gum acacia which served as the control Group 2: Received albendazole suspension at a dose of $10 \mathrm{mg} / \mathrm{mL}$ which served as the standard

Group 3: Received methanolic extract at a dose of $50 \mathrm{mg} / \mathrm{mL}$ Group 4: Received methanolic extract at a dose of $100 \mathrm{mg} / \mathrm{mL}$ Group 5: Received aqueous extract at a dose of $50 \mathrm{mg} / \mathrm{mL}$ Group 6: Received aqueous extract at a dose of $100 \mathrm{mg} / \mathrm{mL}$.

Anthelmintic potential of methanolic and aqueous extracts of rhizomes of $A$. propinquum was carried out using the method previously described by Ajaiyeoba et al. 2001, with necessary modifications. ${ }^{[22]}$ The Indian earthworms ( $P$. posthuma) of nearly equal size were taken in Petri plates containing $15 \mathrm{~mL}$ of different concentrations (50 and $100 \mathrm{mg} /$ $\mathrm{mL}$ ) of methanolic and aqueous extracts suspended in normal saline. Albendazole suspension of the same concentration prepared in normal saline was taken as standard. All Petri dishes were kept under room temperature and under close observation. Observation was made for time taken to complete paralysis (PT) and death (DT) for individual worms. Time for paralysis was noted either when any movement could not be observed except when the worms were shaken vigorously or when dipped in warm water $\left(50^{\circ} \mathrm{C}\right)$. Death was included when the worms lost their motility followed by white secretions and fading away of their body color. $^{[23]}$

\section{RESULTS AND DISCUSSION}

\section{Macroscopic characters}

The rhizomes of A. propinquum Schott are spherical in shape with light brown color outside and cream color inside with pungent odor and 
astringent taste. The outer covering of the rhizomes is smooth and is of varying size ranging from 2 to $6 \mathrm{~cm}$ in diameter [Figure 1].

\section{Microscopic characters}

The transverse section (TS) of the rhizomes was circular in outline and showed the outer multilayered cortex cells, parenchymatous cells, schizogenous intercellular cavities, and well-developed xylem and phloem vessels [Figure 2]. The powdered microscopy of the rhizomes revealed the presence of cork cells, reticulate vessels, and prismatic calcium oxalate crystals [Figure 3].

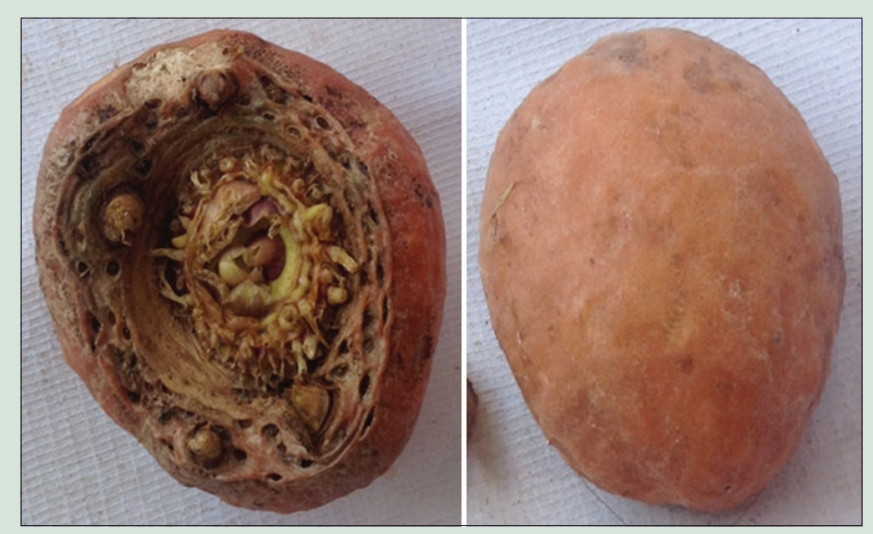

Figure 1: Rhizomes of Arisaema propinquum Schott

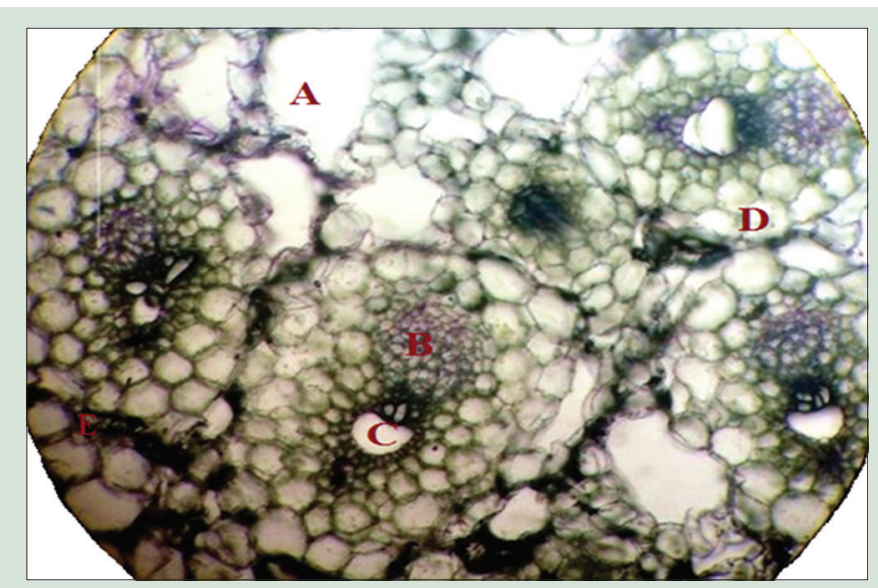

Figure 2: TS of Arisaema propinquum rhizome shows (A) schizogenous intercellular sacs, (B) xylem vessels, (C) phloem vessels, (D) parenchymatous cells, (E) cork cells

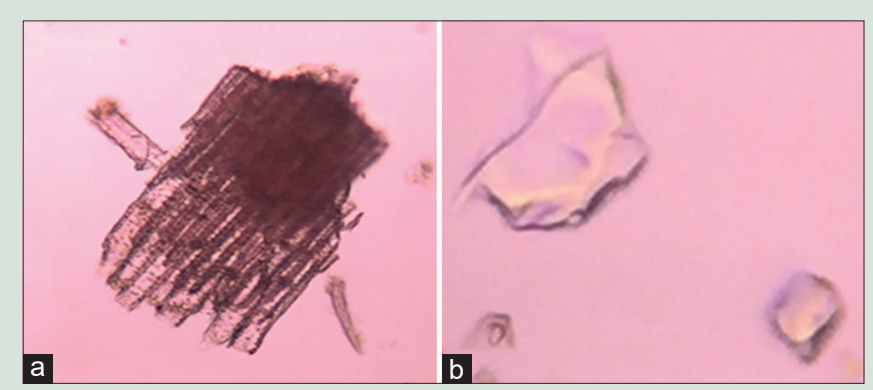

Figure 3: Powder microscopy of Arisaema propinquum showed (a) reticulate vessels, (b) prismatic calcium oxalate crystals

\section{Physicochemical analysis}

For the evaluation of pharmacognostic characters of $A$. propinquum Schott rhizomes, various physicochemical parameters were studied. $A$. propinquum rhizomes showed the presence of total ash $-6.32 \%$, acid insoluble ash $-1.77 \%$, water-soluble ash $-5.15 \%$, sulfated ash $-8.55 \%$, moisture content $-18.50 \%$, swelling index $-25.66 \%$, and foreign organic matter $-1.1 \%$ [Table 1]. For determination of the extractive value, the powdered drug was extracted by three methods, namely cold extraction, hot extraction, and successive extraction [Table 2]. The fluorescence analysis, an important parameter for the determination of quality and purity of powdered drug material, was also evaluated [Table 3]. The powered drug is also tested for heavy metal analysis using AAS [Table 4].

Table 1: Physiochemical analysis of rhizomes of Arisaema propinquum

\begin{tabular}{lc}
\hline Parameters & Content obtained \\
\hline Total ash value $(\% \mathrm{w} / \mathrm{w})$ & 6.325 \\
Acid insoluble ash value (\%w/w) & 1.77 \\
Water-soluble ash value $(\% \mathrm{w} / \mathrm{w})$ & 5.15 \\
Sulfated ash value $(\% \mathrm{w} / \mathrm{w})$ & 8.55 \\
Foreign organic matter $(\% \mathrm{w} / \mathrm{w})$ & 1.1 \\
Loss on drying $(\% \mathrm{w} / \mathrm{w})$ & 18.50 \\
Swelling index $(\% \mathrm{w} / \mathrm{w})$ & 25.66 \\
Foaming index & $<100$ \\
Total tannin content $(\% \mathrm{w} / \mathrm{w})$ & 7.15 \\
Total fat content $(\% \mathrm{w} / \mathrm{w})$ & 1.68 \\
$\mathrm{pH}$ of $1 \%$ solution & 6.50 \\
$\mathrm{pH}$ of $10 \%$ solution & 6.75 \\
\hline
\end{tabular}

Table 2: Extractive values of rhizome part of Arisaema propinquum

\begin{tabular}{lcc}
\hline Extractive values & Methanolic (\%) & Aqueous (\%) \\
\hline Cold extractive value & 12.8 & 10.3 \\
Hot extractive value & 15.9 & 15.2 \\
Successive extractive value & 16.7 & 14.8 \\
\hline
\end{tabular}

Table 3: Fluorescence analysis of Arisaema propinquum rhizomes

\begin{tabular}{|c|c|c|c|}
\hline Experiment & $\begin{array}{l}\text { Visible/ } \\
\text { daylight }\end{array}$ & $\begin{array}{l}\text { UV light } \\
(254 \mathrm{~nm})\end{array}$ & $\begin{array}{l}\text { UV light } \\
(365 \mathrm{~nm})\end{array}$ \\
\hline Powder as such & Greyish brown & Greyish brown & Black \\
\hline Drug + water & Light brown & Greenish brown & Black \\
\hline Drug + acetone & Greyish brown & Greenish brown & Black \\
\hline Drug + pet ether & Greyish brown & black brown & Black \\
\hline Drug $+\mathrm{CHCl}_{3}$ & Dark brown & Greenish brown & Black \\
\hline Drug + ethyl acetate & Dark brown & Greyish brown & Black \\
\hline Drug + methanol & Greyish green & Greenish brown & Black \\
\hline $\begin{array}{l}\text { Drug + glacial acetic } \\
\text { acid }\end{array}$ & Brown & Greyish brown & $\begin{array}{l}\text { Dark } \\
\text { brown }\end{array}$ \\
\hline Drug $+\mathrm{NH}_{3}$ & Light brown & Greenish brown & Black \\
\hline $\begin{array}{l}\text { Drug }+\mathrm{HNO}_{3} \\
\text { (Concentrated) }\end{array}$ & Reddish brown & Greenish brown & Black \\
\hline $\begin{array}{l}\text { Drug }+\mathrm{HNO}_{3} \\
\text { (Diluted) }\end{array}$ & Reddish brown & Greenish brown & Black \\
\hline $\begin{array}{l}\text { Drug + HCL } \\
\text { (Concentrated) }\end{array}$ & Dark brown & Black brown & Black \\
\hline Drug + HCL (Diluted) & Brown & Greenish brown & Black \\
\hline Drug $+\mathrm{H}_{2} \mathrm{SO}_{4}$ & Brown & $\begin{array}{l}\text { Dark greenish } \\
\text { brown }\end{array}$ & Black \\
\hline $\begin{array}{l}\text { Drug }+\mathrm{H}_{2} \mathrm{SO}_{4} \\
\text { (Diluted) }\end{array}$ & Brown & Dark brown & Black \\
\hline Drug + Picric acid & Yellowish brown & Greenish brown & Black \\
\hline Drug $+5 \% \mathrm{NaOH}$ & Dark brown & Greenish brown & Black \\
\hline Drug $+5 \% \mathrm{FeCl}_{3}$ & Greyish green & Greenish black & Black \\
\hline
\end{tabular}




\section{Phytochemical analysis}

The results of qualitative phytochemical analysis of A. propinquum Schott rhizomes are shown in Table 5. The rhizomes showed the presence of alkaloids, carbohydrates, cardiac glycosides, coumarins, proteins, amino acids, phenols, tannins, flavonoids, saponins, steroids, and terpenoids.

The anthelminthic activity of methanolic and aqueous extracts of $A$. propinquum Schott was evaluated against Indian adult earthworms $(P$. posthuma) due to its similar anatomical and physiological resemblance with the intestinal worms. Methanolic and aqueous extracts of $A$. propinquum Schott showed dose-dependent anthelminthic activity as

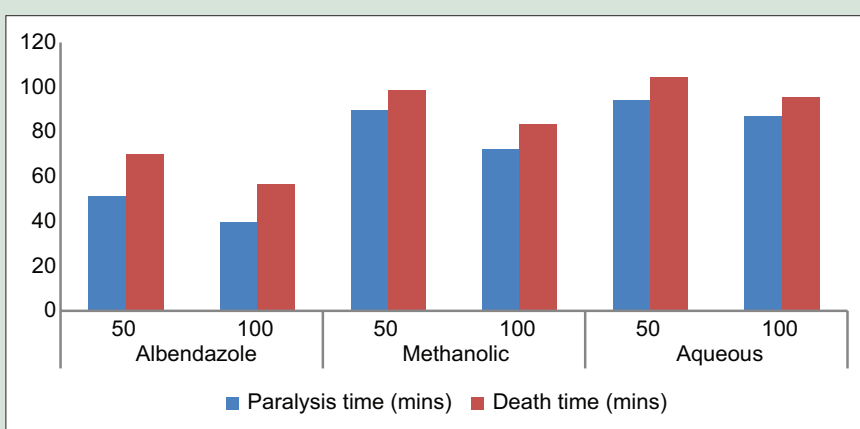

Figure 4: Death time and paralysis time of methanolic and aqueous extracts of Arisaema propinquum

Table 4: Heavy metal content in the rhizome of Arisaema propinquum

\begin{tabular}{lll}
\hline $\begin{array}{l}\text { Heavy } \\
\text { metal }\end{array}$ & $\begin{array}{l}\text { Heavy metal } \\
\text { in drug }(\mathrm{ppm})\end{array}$ & $\begin{array}{l}\text { Permissible limit of heavy } \\
\text { metals in crude drugs }(\mathbf{p p m})\end{array}$ \\
\hline $\begin{array}{l}\text { Arsenic } \\
\text { Cadmium }\end{array}$ & Not detected & NMT $10.0 \mathrm{ppm}$ \\
Lead & Not detected & NMT $0.3 \mathrm{ppm}$ \\
Mercury & Not detected & NMT $1.0 \mathrm{ppm}$ \\
\hline
\end{tabular}

NMT: Not more than

Table 5: Phytochemical screening of rhizome of Arisaema propinquum

\begin{tabular}{lcc}
\hline Plant constituent & Methanol extract & Aqueous extract \\
\hline Alkaloids & + & + \\
Carbohydrates & + & + \\
Anthraquinone glycosides & - & - \\
Cardiac glycosides & + & + \\
Coumarin & + & + \\
Proteins and amino acids & + & + \\
Flavonoids & + & + \\
Steroids and terpenoids & + & + \\
Saponins & + & + \\
Resin & - & - \\
Tannins and phenolics & + & + \\
\hline
\end{tabular}

+: indicates Present, -: indicates Absent

Table 6: Anthelminthic activity of methanolic and aqueous extracts of Arisaema propinquum

\begin{tabular}{lccc} 
Treatment & $\begin{array}{c}\text { Concentration } \\
\mathrm{mg} / \mathrm{mL}\end{array}$ & $\begin{array}{c}\text { Paralysis } \\
\text { time (min) }\end{array}$ & $\begin{array}{c}\text { Death } \\
\text { time (min) }\end{array}$ \\
\hline Control & - & - & - \\
Albendazole & 50 & $51.40 \pm 0.81$ & $70.2 \pm 1.15$ \\
Methanolic & 100 & $39.60 \pm 0.92$ & $56.6 \pm 1.80$ \\
& 50 & $89.53 \pm 3.07$ & $98.4 \pm 1.05$ \\
Aqueous & 100 & $72.02 \pm 0.56$ & $83.41 \pm 1.45$ \\
& 50 & $94.20 \pm 1.02$ & $104.2 \pm 1.24$ \\
& 100 & $86.76 \pm 3.01$ & $95.33 \pm 2.11$ \\
\hline
\end{tabular}

compared to standard albendazole. However, methanolic extract showed potent activity as compared to aqueous extract [Table 6 and Figure 4].

\section{Statistical analysis}

Results are expressed as mean \pm standard error mean $(n=6)$, and the comparisons are made by ANOVA followed by Tukey's test. GraphPad Prism 6 (GraphPad Software, San Diego, California) was used for the analyses.

The present endeavor of the study is to establish, as possible, the diagnostic characteristics of $A$. propinquum Schott rhizomes. In this regard, the macro- and microscopic study was carried out, showed the rhizomes are spherical in shape with light brown color outside and cream color inside with pungent odor and astringent taste. The TS of the rhizome showed the multilayered cortex cells, parenchymatous cells, schizogenous intercellular cavities, and well-developed xylem and phloem vessels. Physiochemical analysis showed $6.32 \%$ total ash, 1.77\% acid insoluble ash, 5.15\% water-soluble ash, and $8.55 \%$ sulfated ash. Extractive values, which are important parameters for the evaluation of crude drugs, determine the amount and nature of chemical constituents present within the crude drug. The $\mathrm{pH}$ value provides information about the acidic or basic nature of constituents present in the crude drug. For quality assurance, it is necessary to perform heavy metal analysis of the crude drug which was carried out according to the wet digestion method, and the results showed the absence of heavy metals in the crude drug indicating their safety for human consumption. The phytochemical analysis of the extracts showed the presence of alkaloids, carbohydrates, cardiac glycosides, coumarins, proteins and amino acids, phenols, tannins, flavonoids, saponins, steroids, and terpenoids.

Anthelminthic activity of methanolic and aqueous extracts was evaluated against Indian adult worm (P. posthuma). Both methanolic and aqueous extracts of $A$. propinquum Schott rhizomes showed good anthelmintic activity in a dosage-dependent manner. Methanol extract showed the highest anthelmintic activity as compared to aqueous and standard drug albendazole.

\section{CONCLUSION}

This study revealed that methanolic and aqueous extracts of A. propinquum Schott rhizomes possess good anthelminthic activity. Therefore, the extracts mainly methanolic which shows the highest activity has the potential for development as an anthelminthic agent against helminthic diseases which however needs further study to understand the underlying mechanism of extracts as an anthelminthic agent. Also, the data generated from the pharmacognostic and phytochemical analysis can be used as a standard in the quality control of this plant.

\section{Acknowledgements}

The authors are very thankful to the Head, Department of Pharmaceutical Sciences, University of Kashmir, Srinagar, J and K, India, for providing the laboratory equipment and necessary facilities and to conduct this study.

\section{Financial support and sponsorship \\ Nil.}

\section{Conflicts of interest}

There are no conflicts of interest.

\section{REFERENCES}

1. Mubashir S, Shah WA. Arisaema propinquum: A plant with potential as antibacterial, antioxidant and anticancer agent. Drug Invent Today 2012;4:345-7. 
2. Available from: http://soulesgarden.com/index.php?main_page=product_info and products_id=4439. [Last accessed on 2018 Jul 22]

3. Sher H, Bussmann RW, Hart R, de Boer HJ. Traditional use of medicinal plants among Kalasha, Ismaeli and Sunni groups in Chitral District, Khyber Pakhtunkhwa Province, Pakistan. J Ethnopharmacol 2016;188:57-69.

4. Kaul MK. Medicinal plants of Kashmir and Ladakh, Temperate and Cold Arid Himalaya. Regional Research Laboratory (C.S.I.R) Jammu. Indus Publishing House, New Delhi; 1997;173:100.

5. Bhatt VP, Negi GC. Ethnomedicinal plant resources of Jaunsari tribe of Garhwal Himalaya, Uttaranchal. Indian J Trad Knowl 2006;5:331-5.

6. Tagboto S, Townson S. Antiparasitic properties of medicinal plants and other naturally occurring products. Adv Parasitol 2001;50:199-295.

7. Idika IK, Okonkwo EA, Onah DN, Ezeh IO, Iheagwam CN, Nwosu CO. Efficacy of levamisole and ivermectin in the control of bovine parasitic gastroenteritis in the sub-humid savanna zone of southeastern Nigeria. Parasitol Res 2012;111:1683-7.

8. Hossain E, Chandra G, Nandy AP, Mandal SC, Gupta JK. Anthelmintic effect of a methanol extract of leaves of Dregea volubilis on Paramphistomum explanatum. Parasitol Res 2012;110:809-14

9. Patil DA. Flora of Dhule and Nandurbar Districts. Dehradun, UP, India: Bishen Singh Mahendra Pal Singh; 2003. p. 571.

10. Nikunz K, Naidu D, Ramu VN, Sampath K. Anti-inflammatory and anti-helminthic activity of ethanolic extract of Azadirachta indica leaves. Int J Green Pharm 2016;10:200

11. Ferreira LE, Castro PM, Chagas AC, França SC, Beleboni RO. In vitro anthelmintic activity of aqueous leaf extract of Annona muricata L. (Annonaceae) against Haemonchus contortus from sheep. Exp Parasitol 2013;134:327-32.

12. Evans WC, Evans D, Trease GE. Trease and Evan's Pharmacognosy. $16^{\text {th }}$ ed International Edition E-Book. Elsevier Health Sciences: Saunders/Elsevier;
2009.

13. Trease GE, Evans WC. Pharmacognosy. International ed., Vol. 2. International Edition E-Book. Elsevier Health Sciences: WB Saunders; 2008. p. 53844.

14. Quality Control Methods for Herbal Materials. WHO Library Cataloguing in Publication Data. Vol. 9. World Health Organization; 2011.p. 45-9.

15. Mukherjee PK. Quality Control Herbal Drugs: An Approach to Evaluation of Botanicals. $4^{\text {th }}$ ed. New Delhi: Business Horizons Pharmaceutical Publishers; 2008. p. 183-95

16. Mukherjee KP. Quality Control of Herbal Drugs: An Approach to Evaluation of Botanicals. New Delhi: Business Horizons; 2002. p. 426-83.

17. Sharma SK, Singh AP. Morphological, microscopical and physico-chemical investigations on the rhizomes of Cyperus rotundus Linn. Res J Pharm Biol Chem Sci 2011;2;798

18. Mukherjee PK. Quality Control of Herbal Drug. $1^{\text {st }}$ ed. New Delhi: Business Horizons Pharmaceutical Publishers; 2010. p. 184-91.

19. Tiwari P, Kumar B, Kaur M, Kaur G, Kaur H. Phytochemical screening and extraction: A review. Int Pharm Sci 2011;1:98-106.

20. Menpara D, Chanda S. Phytochemical and pharmacognostic evaluation of leaves of Pongamia pinnata L. (Fabaceae). Pharmacogn Commun 2014;4:3-7.

21. Okalebo JR, Gathua KW, Woomer PL. Laboratory methods of soil and plant analysis: A working manual; TSBF-KARI, Nairobi, Kenya; Okinawa, Japan. Commun Soil Sci Plant Anal 2002;31:277-88.

22. Ajaiyeoba EO, Onocha PA, Olarenwaju OT. In vitro anthelmintic properties of Buchholzia coriaceae and Gynandropsis gynandra extracts. Pharm Biol 2001;39:217-20

23. Gnaneswari $K$, Padma Y, Venkata Raju RR, Jayaveera KN. In vitro anthelmintic activity of Leonotis nepetiifolia (L.) R. Br. a potential medicinal plant. J Chem Pharm Res 2013;5:345-8. 